\title{
STRATEGI KOMUNIKASI PEMASARAN PRODUK FAIR N PINK MELALUI MEDIA SOSIAL INSTAGRAM
}

\author{
Iik Arif Rahman, Redi Panuju \\ Universitas dr. Soetomo Surabaya \\ redi.panuju@unitomo.ac.id \\ Diajukan: 08-11-2017; Direview: 27-11-2017; Diterima: 11-12-2017;
}

\begin{abstract}
The ease of getting information via the internet, supported by several social media chat applications has changed the pattern of selling goods by entrepreneurs. The focus of this research is abaout product marketing communication strategy through Instagram. Through the account Instagram@Fair N Pink Surabaya as an online marketing communication media in running business promotion. The purpose of this study is to find out the marketing strategy of Fair N Pink through Instagram. This research uses Marketing Communications concepts and a descriptive qualitative method. The theory used is the marketing communications theory. The conclusion of marketing strategy of Fair $N$ Pink product marketing through social media to run online marketing communication strategy by utilizing the features in instagram.
\end{abstract}

Keywords: Marketing communication, online marketing, social media, Instagaram.

\begin{abstract}
Abstrak
Mudahnya mendapatkan informasi dalam akses internet yang didukung dengan adanya beberapa aplikasi chating media sosial telah merubah pola penjualan barang oleh para pengusaha. Strategi komunikasi pemasaran produk secara online melalui akun Instagram menjadi fokus penelitian pada penulisan jurnal ini. Akun @Fair N Pink Surabaya menggunakan Instagram sebagai media komunikasi pemasaran secara online dalam menjalankan promosi bisnisnya. Penelitian ini untuk mengetahui strategi komunikasi pemasaran produk Fair N Pink melalui media sosial Instagram. Adapun metode yang digunakan dalam penelitian ini adalah metode deskriptif kualitatif. Sementara teori yang digunakan adalah teori komunikasi pemasaran. Simpulannya strategi komunikasi pemasaran produk Fair N Pink melalui media sosial instagram Fair N Pink Surabaya memanfaatkan instagram dalam menjalankan strategi komunikasi pemasaran online dengan memanfaatkan fitur yang ada di dalam instagram.
\end{abstract}

Kata kunci: komunikasi pemasaran, pemasaran Online, media sosial, instagram

\section{PENDAHULUAN}

$\mathrm{P}$ erkembangan teknologi beberapa dekade ini sangat pesat menguasai lini kehidupan manusia.Salah satu teknologi yang perkembangannya semakin pesat adalah teknologi internet, teknologi dunia maya ini merupakan teknologi yang menjadi tren untuk semua kalangan. Dengan internet setiap orang dapat berkomunikasi dengan orang lain yang berada di berbagai belahan dunia tanpa di batasi waktu dan ruang. Kini siapa saja yang memiliki perangkat untuk terhubung ke internet melalui komputer, smartphone maupun perangkat sejenisnya dapat menjadi bagian dari jaringan komunikasi dunia (Poetra dan Christantyawati, 2017). Transaksi di toko online mempunyai proses transaksi yang jauh berbeda, bila di toko biasa kita di layani oleh manusia, sebenarnya hampir sama saja kita juga dilayani oleh manusia tapi yang membedakannya kita di layani tidak face to face, saat berbelanja secara langsung kita menghabiskan waktu dijalan sedang untuk berbelanja online shop kita bisa duduk santai bahkan sambil tiduran tanpa perlu banyak membuang waktu (Poetra dan Christantyawati, 
2017). Keputusan yang diambil oleh konsumen untuk membeli suatu produk, umumnya dipengaruhi oleh alasan kebutuhan akan konsumsi barang tersebeut. Pada sisi lainnya, terdapat alasanalasan di luar dari sekedar kebutuhan semata yang diberikan konsumen dalam mengambil sebuah keputusan pembelian, diantaranya seperti keinginan untuk mencoba produk baru, ataupun juga rasa penasaran dengan produk yang iklannya sering dimunculkan. Dalam kaitannya dengan pemikiran ini, pelaku usaha maupun perusahaan mulai mendekatkan diri kepada para konsumen melalui sebuah promosi berupa pembuatan iklan, baik di media cetak maupun media elektronik.

Seiring dengan perkembangannya, internet mampu melahirkan suatu jaringan baru yang biasa di kenal dengan sebutan media sosial. Media sosial merupakan sebuah media online yang memudahkan orang untuk berpartisipasi, berbagi, dan menciptakan isi meliputi blog, jejaring sosial, wifi, forum dan dunia virtual. Awalnya media sosial hanya digunakan sebagai sarana berkomunikasi untuk terhubung dengan teman, rekan kerja dan keluarga. Namun pada perkembangannya, media sosial tidak hanya digunakan sebatas itu saja. Media sosial kini banyak digunakan untuk menyebarluaskan atau memberikan berbagai informasi, mulai dari informasi politik, bisnis, pendidikan, kuliner, kesehatan, budaya, hiburan, hingga kegiatan promosi produk.

Mudahnya akses internet sebagai sarana untuk mendapatkan informasi, kini banyak perusahaan atau kelompok tertentu menggunakan media sosial untuk menjalankan fungsi komunikasi (menjalin komunikasi dengan konsumen) dan fungsi penjualan. Media sosial kini sudah beralih menjadi media promosi barang dagangan. Para penggunanya memanfaatkan Twitter, Facebook, Instagram, bahan grup fitur chatting seperti BBM untuk keperluan tersebut. Hal ini bisa dilihat dengan banyaknya individu, kelompok, dan perusahaan yang memilih media sosial seperti facebook, Twitter, atau Instagram sebagai media untuk memperkenalkan profil, membangun interaksi dengan konsumen dan mempromosikan produknya. Banyaknya perusahaan atau pemasar menggunakan media sosial sebagai media untuk beriklan atau melakukan promosi atas produknya ini merupakan sebuah alternatif yang dapat meminimalisir buget pengeluaran untuk biaya promosi, jika dibandingkan dengan beriklan melalui media cetak, media audio, maupun media audiovisual, beriklan melalui media sosial (internet) tentu jauh lebih murah dan efesien. Dikutip dari profile.print.kompas. com/tariff-iklan/, pada tabel dibawah ini menunjukkan betapa mahalnya biaya beriklan di media cetak sekelas Kompas yang notabennya surat kabar nasional.

Tabel 1. Tarif Iklan Reguler Surat Kabar Kompas

\begin{tabular}{|c|c|}
\hline Jenis Iklan & Harga \\
\hline \multicolumn{2}{|c|}{ Display (per mmk) } \\
\hline Hitam-Putih (min 40 mmk) & Rp 147.000 \\
\hline Berwarna $(\min 810)$ & Rp 197.000 \\
\hline \multicolumn{2}{|c|}{ Advertorial } \\
\hline Hitam-Putih (min $810 \mathrm{mmk}$ ) & Rp 151.500 \\
\hline Berwarna (min $810 \mathrm{mmk}$ ) & Rp 201.500 \\
\hline \multicolumn{2}{|c|}{ Prospektus } \\
\hline Hitam-Putih (min 40 mmk) & Rp 68.000 \\
\hline Berwarna (min $810 \mathrm{mmk})$ & Rp 99.000 \\
\hline
\end{tabular}

Sumber :http://profile,print.kompas.com/tarif-iklan/

Dari tabel diatas dapat diprediksi besarnya biaya promosi untuk sekali beriklan di media cetak, dengan menggunakan media sosial untuk beriklan tentu menjadi pilihan yang tepat bagi pemasar yang ingin memangkas biaya promosi. Seperti halnya pemilik akun@FairNPink Surabaya yang memanfaatkan media sosial Instagram dalam mempromosikan produknya. Saat ini Instagram menjadi tempat strategis para pembisnis dalam memasarkan produknya, menurut hasil penelitian dari perusahaan analisis bisnis SumAll. Disebutkan dalam Digital Trends tempo.com bahwa Instagram menjadi media sosial paling sukses untuk berjualan, hal ini dikarenakan Instagram mampu menyajikan konten barang dengan visual yang menarik. Sehingga pengguna merasa lebih nyaman menikmatinya.

Selama ini promosi yang dilakukan akun@ 
FariNPink Surabaya dalam upaya memasarkan produknya hanya dilakukan melalui akun media sosial. Yakni dengan mem-posting pesan dan gambar iklan melalui akun Instagram-nya. Meskipun promosi hanya dilakukan melalui media sosial, namun promosi tersebut berhasil memikat konsumen (followers), membuat followers tertarik untuk memiliki produk tersebut, sehingga produkproduknya laris dibeli konsumen (followers). Hal ini yang membuat peneliti tertarik melakukan penelitian lebih lanjut, yaitu ketika sebuah perusahaan memasarkan produknya hanya dengan melakukan promosi atau beriklan melalui media sosial, tanpa di sertai bauran lain seperti personal selling, beriklan dimedia cetak maupun elektronik, tetapi produknya laris terjual. Kesuksesan promosi yang hanya melalui media sosial ini tentu terkait dengan strategi komunikasi pemasaran, strategi pesan iklan yang di-posting pada akun media sosial tersebut, strategi tentang membuat pesan iklan yang efektif dan dapat memikat hati konsumen sehingga konsumen berkeinginan untuk membeli produk dan ahirnya benar-benar membeli produk tersebut.

Swastha mendefinisikan strategi sebagai serangkaian rancangan yang menggambarkan bagaimana sebuah perusahaan harus beroprasi untuk mencapai tujuannya (Hermawan, 2012:33). West dan Turner (2008:5) mendefinisikan komunikasi sebagai proses sosial dimana individu-individu menggunakan simbol-simbol untuk menciptakan dan menginterpretasikan makna dalam lingkungan mereka. Menurut W.Y Stanton pemasaran adalah sesuatu yang meliputi sistem yang berhubungan dengan tujuan untuk merencanakan dan menentukan harga sampai dengan mempromosikan dan mendistribusikan barang dan jasa yang bisa memuaskan kebutuhan pembeli aktual maupun potensial (Hermawan, 2012:33). Strategi komunikasi pemasaran merupakan langkah-langkah kreatif yang berkesinambungan yang diupayakan oleh sebuah perusahaan guna mencapai target pemasaran terbaik dalam rangka mewujudkan kepuasan konsumen secara maksimal. Strategi komunikasi pemasaran adalah cara yang ditempuh perusahaan untuk merealisasikan misi, tujuan, dan sasaran yang telah ditentukan dengan cara menjaga dan mengupayakan adanya keserasian antara berbagai tujuan yang ingin dicapai, kemampuan yang dimiliki serta peluang dan ancaman yang dihadapi dipasar produknya (Adisaputro, 2010:18).

Dari uraian diatas, peneliti tertarik untuk melakukan sebuah penelitian untuk mengetahui bagaimana strategi komunikasi pemasaran produk yang di lakukan akun@FairNPink Surabaya melalui media sosial Instagram.

\section{LITERATUR DAN METODOLOGI}

Rafa'al (2017:51) menjelaskan pada prinsipnya perilaku konsumen dipengaruhi afeksi dan kognisi konsumen terhadap suatu produk dimana dua faktor tersebut juga dapat dipengaruhi oleh lingkungan serta stimulus yang diberikan oleh pemasar produk itu sendiri. Afeksi dan kognisi konsumen yang bervariasi ini nanti akan menentukan perilaku konsumen terhadap suatu produk maupun merk. Untuk menghasilkan perilaku yang diharapkan, produsen dari suatu produk menerapkan serangkaian strategi-strategi yang menghasilkan luaran yang tidak hanya meningkatkan hasil penjualan, namun juga meningkatkan brand awareness dari produk tersebut.

Poetra dan Christantyawati (2017: 34-35) menjelaskan bahwa penggunaan Internet sebagai medium penjualan di era modern seperti ini, membuat manusia terus menerus ingin berubah dan berkembang untuk memenuhi segala tuntutan era global. Adanya perubahan pola Jual beli online di Internet kini kian merambah jauh dan menjadi sebuah kebutuhan atau gaya hidup masyarakat di era modernisasi dan dimana dapat memberikan keuntungan diantara kedua belah pihak. Baik konsumen selaku pembeli maupun admin atau selaku penjual mendapatkan benefit yang saling menguntungkan bagi kedua belah pihak dengan adanya media toko online tersebut. Febriani (2017:242) memberikan pandangan bahwa perilaku konsumen yang loyal terhadap suatu produk tentu saja menguntungkan bagi produsennya, karena konsumen akan terus berusaha mencari produk yang diinginkannya. Namun demikian, jika konsumen terus-menerus kesulitan mencari produk yang diinginkannya, maka lama-lama konsumen 
akan mencoba merek yang lain. Sementara itu, perilaku konsumen yang tidak loyal, atau dengan perkataan lain membeli suatu tidak hanya karena kebiasaan saja, perlu memperhatikan aspek-aspek lain secara serius.

Dalam mengelola sistem komunikasi pemasaran diperlukan rancangan strategi, program-program penjualan yang efektif dan efisien.Promosi penjualan adalah bagian penting dari strategi komunikasi pemasaran perusahaan dan promosi penjualan merupakan aktivitas pemasaran yang mengusulkan nilai tambah dari suatu produk (untuk mendapatkan dari sekedar yang ada dari nilai produk) dalam jangka beberapa waktu tertentu guna mendorong pembelian konsumen, efektivitas penualan atau mendorong upaya yang dilakukan oleh tenaga penjualan menurut Hermawan (2012:128-129). Dengan demikian, promosi harus di tangani dengan cermat karena masalahnya bukan hanya menyakut pada bagaimana berkomunikasi dengan para konsumen akan tetapi juga menyakut seberapa besar biaya yang dikeluarkan oleh pelaku usaha tentunya hal ini harus di kondisikan sesuai kemampuan pelaku usaha tersebut dan perusahaan.

Kegiatan periklanan adalah media utama bagi perusahaan dalam menunjang promosi di mana promosi memiliki tujuan utama untuk menarik konsumen agar mau melakukan pembelian terhadap produk yang di tawarkan, segala biaya yang harus dikeluarkan sponsor untuk melakukan presentasi dan promosi non pribadi dalam bentuk gagasan,barang atau jasa untuk mempengaruhi audience. Kegiatan promosi yang satu ini bisa dikatakan ujung tombak dari kegiatan promosi, hal ini dikarenakan penjualan personal merupakan kegiatan promosi yang mengharuskan pemasaran berhadapan dengan konsumen secara langsung. Kegiatan penjualan personal yang dilakukan secara profesional akan sangat membantu tercapainya penjualan yang fantastis.

Promosi penjalan mengedepankan penambahan intensitas nilai barang atau jasa, hal ini meliputi berbagai aspek manajeman pemasaran, mulai dari peningkatan kualitas produk, kualitas pelayanan distribusi bagi distributor, meningkatkan kualitas pelayanan bagi pelanggan agar menjadi lebih baik. Secara khusus program-program promosi penjualan meliputi diskon, bantuan pembiyayaan iklan dan bonus dari agen. Cara ini lebih condong untuk membentuk sebuah citra yang lebih positif terhadap produk yang ditawarkan. Sejumlah informasi tentang mengenai seseorang, organisasi, maupun barang yang telah disebarluaskan kepada masyarakat menggunakan media dan tidak dipungut biaya, serta tanpa pengawasan dari sponsor. Riyadi, Sufa, dan Susilo (2017) menjelaskan bahwa citra positif atas produk yang ditawarkan menghasilkan dampak yang positif pula pada penjualan sebuah produk. Dengan demikian maka promosi merupakan kegiatan perusahaan yang dapat dilakukan dalam suatu rangka dimana untuk memperkenalkan sebuah produk kepada konsumen sehingga dengan kegiatan tersebut maka konsumen akan tertarik untuk melakukan pembelian.

Pada penelitian ini, peneliti menggunakan pendekatan Kualitatif dalam menggambarkan strategi tersebut. Menurut (Pawito, 2007:83), metode penelitian meliputi cara dan prinsip berpikir mengenai masalah yang di teliti, pendekatan yang di gunakan, dan prosedur ilmiah yang di tempuh untuk mengumpulkan dan menganalisis data serta menarik kesimpulan. Sedangkan jenis penelitian yang akan di gunakan peneliti adalah deskriptif kualitatif dalam hal ini diartikan sebagai menggambarkan variabel demi variabel, satu persatu. Dapat disimpulkan bahwa laporan penelitian deskriptif merupakan gambaran mengenai laporan penelitian berdasarkan data-data yang telah terkumpul.

Data yang dimaksud dapat berupa hasil pengumpulan dari catatan laporan, wawancara, dokumentasi foto dan video atau bahkan dokumen yang bersifat resmi yang berasal dari objek yang diteliti (Rahmat, 2004: 34-35). Alasan peneliti menggunakan metode ini karena ingin menjelaskan secara mendalam mengenai strategi komunikasi pemasaran yang dilakukan oleh @ Fair N Pink Surabaya. Dalam memikat konsumen melalui media sosial instagram. Amirin (dalam Idrus, 2009:91) menyebutkan bahwa subjek dari penelitian adalah seseorang atau sesuatu mengenainya ingin di peroleh keterangan. Maka subjek dari penelitian ini adalah pemilik akun@ 
Fair N Pink Surabaya. Sedangkan Obyek penelitian adalah sesuatu yang ingin di ketahui oleh peneliti atau yang di teliti dari subjek penelitian. Maka obyek penelitian pada penelitian ini adalah strategi komunikasi pemasaran produk yang dilakukan @ Fair N Pink Surabaya melalui media sosial Instagram.

Unit analisis penelitian ini meliputi delapan fitur yang ada di Instagram di antara Followers, Upload Foto, Stories, Judul Foto, Arroba, Geottagging, Jejaring Sosial, Tanda Suka. Ada dua jenis data yang akan di kumpulkan dalam penelitian ini, yaitu data primer dan sekunder. Data primer merupakan data yang di peroleh secara lansung dari subjek penelitian dengan cara wawancara lansung, sedangkan data sekunder merupakan data pendukung yang di peroleh dari sumber-sumber lain yang relevan dari hasil dokumentasi. Teknik keabsahan data yang akan di gunakan dalam penelitian ini adalah triangulasi sumber data. Triangulasi sumber (triangulasi data) menurut Patton adalah taenik untuk membandingkan dan mengecek baik derajat kepercayaan suatu informasi yang didapat melalui waktu dan alat yang berbeda dalam penelitian kualitatif (Moleong, 2010:330).

\section{TEMUAN DAN DISKUSI}

Di erayang serba canggih dan serbainstan dimana teknologi dan inovasi merupakan perpaduan yang sangat komplit untuk memenuhi kebutuhan serta keinginan manusia. Di era ini juga dimana semua golongan gemar memggunakan media sosial dimana konsumen selalu menginginkan produkproduk yang hasilnya instan dan permanen. Di Indonesia sendiri khususnya anak muda sekarang selalu berbelanja menikuti tren, itu menunjjukkan bahwa perilaku konsumtif anak muda sangat besar dan tentunya mudah menerima produk-produk baru yang ditawarkan. Karena itulah Renny Ina Marlia sebagai pemilik akun Fair N Pink Surabaya memanfaatkan peluang ini dengan sebaik-baiknya, sehingga pada tahun 2015 Renny Ina Marlia merintis karirnya di dunia bisnis online (menjual produk kosmetik) menjadi Distributor resmi dari Fair N Pink, khusus wilayah Sidoarjo dan Surabaya. Fair N Pink produk asli Indonesia yang di produksi di Kota Bekasi.
Selain itu, pemilik usaha memiliki alasan lain dalam memulai bisnis ini. Renny Ina Marlia melihat kondisi wajah anak muda sekarang sangat meris padahal usianya masih muda, wajah cantiknya rusak karena banyaknya produk abalabal yang mengandung bahan-bahan berbahaya. Oleh sebab itu Renny Ina Marlia hadir menawarkan produk baru yang bisa mengobati semua keluhan dan masalah yang ada pada wajah dan tubuh konsumen. Visi: memperluas pemasaran online dan menyediakan produk alami dan Misi:Memberikan kepuasaan yang maksimal untuk pelanggan dengan produk yang inovatif dan berbeda dari kebanyakan kosmetik lainnya.

Dalam Instagram terdapat fitu-fitur yang bisa dimanfaatkan oleh setiap penggunanya. Adapun fitur-fitur yang membantu dalam pemasaran atau promosi barang dan jasa yang di jual secara online. Begitu juga yang di lakukan oleh Fair N Pink Surabaya ini, ada beberapa fitur yang di gunakan oleh Fair N Pink Surabaya sebagai media promosinya melalui Instagram. Strategi akan dikaitkan dengan fitur yang di manfaatkan oleh Fair N Pink Surabaya. Berikut fitur dalam akun Instagram Fair N Pink Surabaya yang telah di manfaatkan sebagai sarana strategi pemasaran online, yaitu:

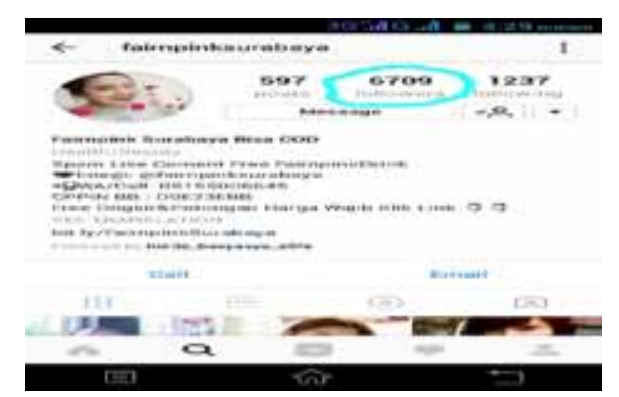

Gambar 1. Jumlah Followers (12 Juli 2017)

(Sumber: screenshots Instagram @

FairNPinkSurabaya oleh peneliti)

Followers adalah salah satu dari beberapa fitur Instagram yang dimaksud dengan menjadi pengikut akun pengguna lain, dan Followers dapat melihat berbagai informasi atau postingan foto yang diUpload oleh akun yang di ikutinya. Fitur ini membantu dalam hal mendapatkan perhatian dan 
kepercayaan dari masyrakat terhadap produknya. Dalam hal menarik perhatian konsumen Fair N Pink Surabaya mempunyai strategi sendiri yang dapat membantu dalam promosinya, strategi tersebut salah satunya dapat kita lihat pada gambar di bawah ini.

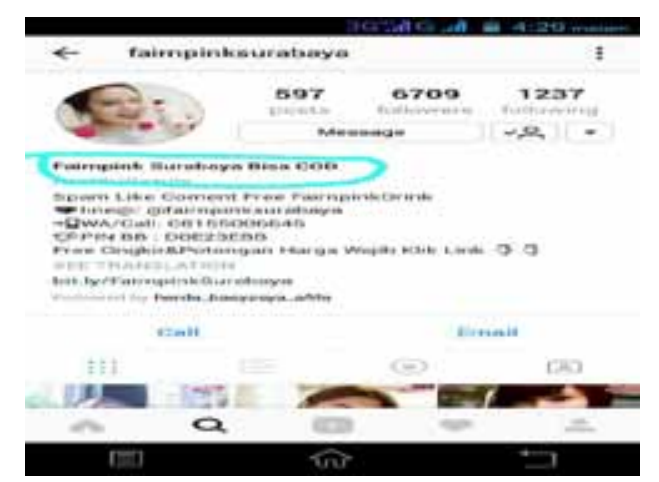

Gambar 2. Profil Fair N Pink Surabaya (Sumber: screenshots Instagram @ FairNPinkSurabaya oleh peneliti)

Keunikan dari strategi promosi akun Fair N Pink Surabaya ini dapat kita lihat dari gambar 2. akun@Fair N Pink Surabaya menyediakan layanan COD (Cash On Delivery) merupakan layanan transaksi jual beli dimana pihak buyer bersedia untuk membayar barang jika pihak seller mengantarkan barang sampai ke alamat tujuan. Namun berbeda dengan salah satu akun yang juga menjual produk Fair N Pink melalui media sosial Instagram, perbedaan itu dapat kita lihat pada gambar di bawah ini:

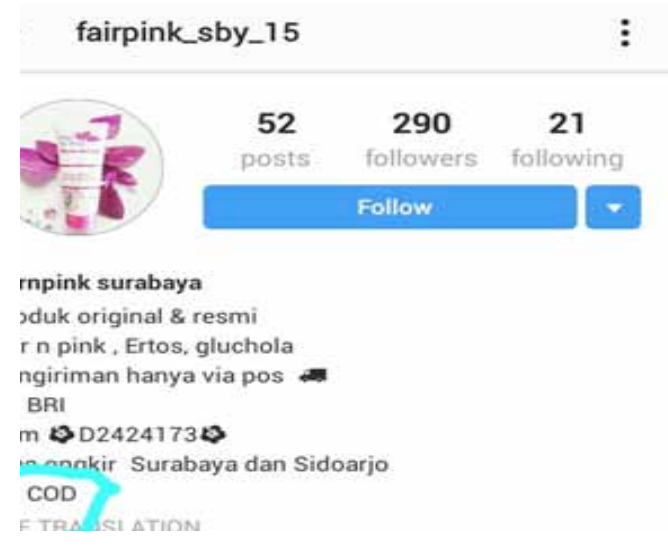

Gambar 3. Profil fairpink_sby_15

(Sumber: screenshots Instagram @fairpink_sby_15 oleh peneliti)
Dari gambar 3 dapat kita lihat akun@fairpink sby_15, pihaknya tidak menyediakan COD, padahal kalau kita lihat keuntungan dan kelebihan COD, untuk kenyamanan konsumen, pertama konsumen bisa melihat langsung kondisi barang, bahkan mencobanya terlebih dahulu. Kedua konsumen bisa menawar harga atau bernegosiasi secara langsung setelah melihat barang. Ketiga konsumen didak kehilngan uang untuk biaya kirim. Bagi penjual transaksi COD tentu bisa membuat citra penjual lebih baik lagi, dan dicap sebagai penjual terpercaya. Dalam hal strategi pemasaran tidak hanya menyediakan layanan COD, tetapi Fair N Pink Surabaya juga memberlakukan free ongkos kirim dan potongan harga seperti kita lihat pada gambar di bawah ini:

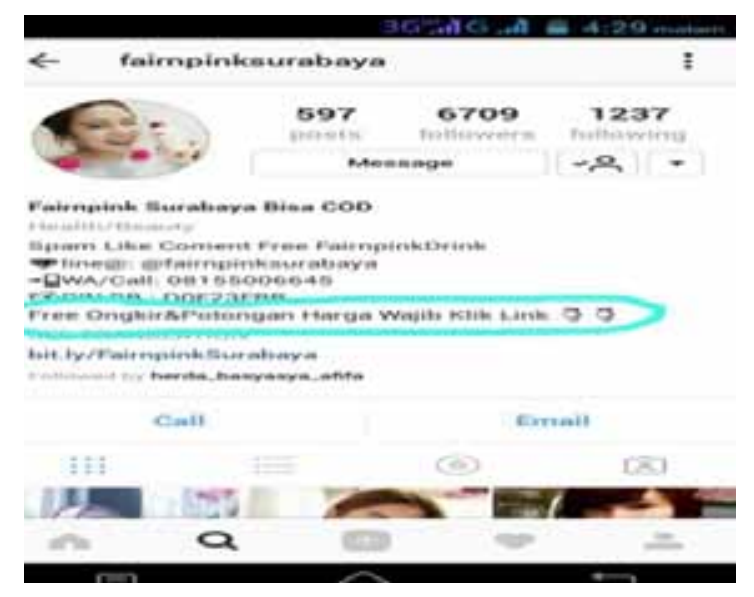

Gambar 4. Profil Fair N Pink Surabaya (Sumber: screenshots Instagram @ FairNPinkSurabaya

Dalam hal pengiriman akun@Fair N Pink Surabaya memberlakukan free ongkos kirim, strategi promo gratis ongkos kirim ini mampu mendapatkan pelanggan yang loyal, karena siapapun pasti tertarik dengan penawaran produk yang menggeratiskan ongkos kirim. Pembeli merasa di untungkan karena ongkos kirim yang seharusnya di tanggung pembeli menjadi hilang. Dalam hal ongkos kirim Fair N Pink Surabaya tidak membatasi wilayah tetapi memberikan subsidi ongkos kirim sebesar Rp. 20.000 jadi kalau ongkos kirimnya di bawah Rp. 20.000 biaya pengeriman gratis dan konsumen akan mendapatkan potongan harga jika membeli lebih dari tiga produk Fair N 
Pink. Strategi free ongkos kirim memang sudah banyak di lakukan para pengusaha online seperti halnya pada akun@fairpink_sby_15 pada gambar di bawah ini:

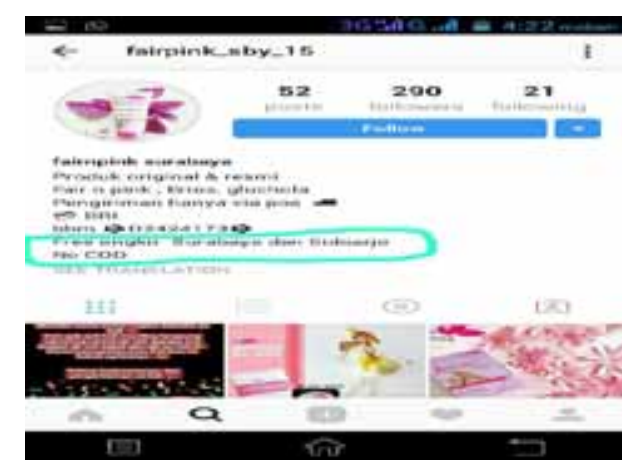

Gambar 5. Profil fairpink_sby_15

(Sumber: screenshots Instagram @fairpink_sby_15 oleh peneliti)

Seperti yang terlihat pada gambar 5. akun@ fairpink_sby_15 juga memberlakukan free ongkos kirim tetapi bedanya, pihaknya membatasi wilayah pengiriman yaitu hanya untuk wilayah Surabaya dan Sidoarjo saja sedangkan akun@ Fair N Pink Surabaya tidak membatasi wilayah tetapi memberikan subsudi Rp.20.000 untuk biaya pengiriman, dalam hal ini peneliti melihat keunikan dari strategi yang di gunakan Fair N Pink Surabaya karena tidak membatasi wilayah sehingga layanan ini dapat juga di rasakan konsumen dari luar Surabaya dan Sidoarjo asalkan biaya pengiriman tidak lebih dari Rp.20.000 dan di tambah lagi dengan layanan potongan harga yang bisa membuat konsumen lebih tertarik untuk membeli produk FairNPink di akun@Fair N Pink Surabaya. Di samping itu Fair N Pink Surabaya juga mempunyai strategi yang tidak di miliki akun lain, strategi tersebut dapat kita lihat pada gambar di bawah ini.

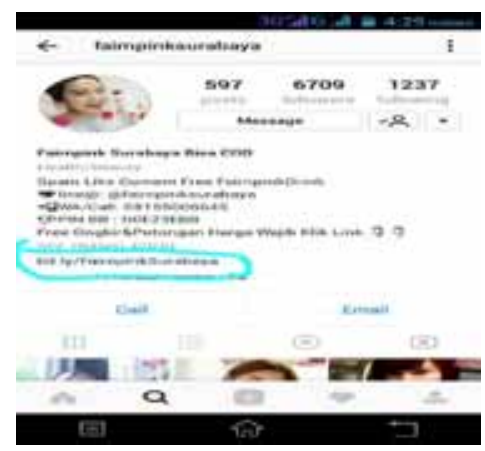

Gambar 6. Profil Fair N Pink Surabaya

(Sumber: screenshots Instagram @

FairNPinkSurabaya oleh peneliti)

Dari gambar 6. dapat kita lihat kalau Fair N Pink Suarabaya menggunakan link diamana ling ini berfungsi untuk memudahkan para konsumen jika ingin memesan atau sekedar penasaran dan ingin mengetahui lebih banyak tentang produk Fair N Pink, konsumen tinggal meng-clik link bit. ly/FairnpinkSurabaya saat konsumen meng-clik link itu maka otomatis akan terhubung dengan kontak Whatsapp Fair N Pink Surabaya, jika sudah terhubung dengan kontak Watshap, konsumen tidak perlu bingung karena admin dari Fair N Pink Surabaya sudah siap melayani segala bentuk pertayaan maupun keluhan mengenai produk Fair N Pink.

Pada media sosial Instagram, hal yang paling ditekankan adalah foto. Karena disinilah para mengguna lain dapat memanjakan mata mereka dengan melihat postingan-postingan foto dari pengguna lain. Upload foto di Instagram ini, memang sangat penting bagi para pebisnis online untuk menawarkan produk jualannya. Banyak hal yang dapat di lakukan pembisnis dalam mempromosikan produknya melalui instagram karena di dukung fitu-fitur yang cocok sebagai pemasaran online, salah satunya fitur upload foto ini, yang di manfaatkan pemilik Fair N Pink Suarabaya untuk mempromosikan produknya, Dari berbagai foto yang di upload Fair N Pink Suarabaya rata-rata produknya di dukung oleh berbagai artis kelas atas maupun kelas bawa. Seperti yang dapat kita lihat pada gambar di bawah ini:

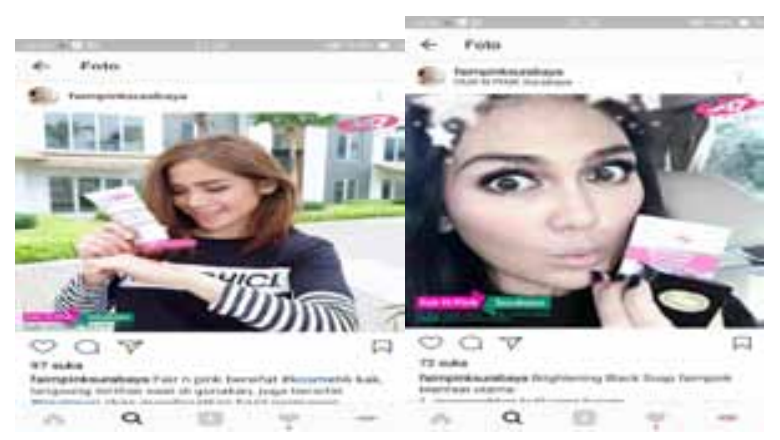




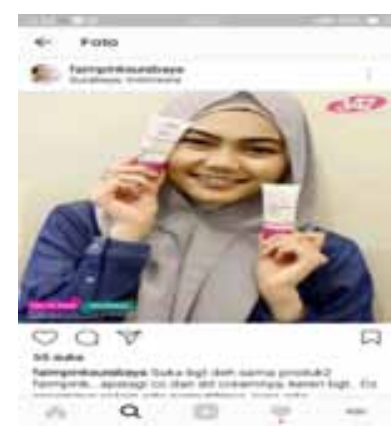

Gambar 7. Gambar endorse Fair N Pink Surabaya (Sumber: screenshots Instagram @FairNPinkSurabaya oleh peneliti)

Dari gambar 7. dapat kita ketahui, bahwa Fair N Pink Suarabaya dalam mempromosikan produknya melakukan iklan endorser, yaitu menggunakan artis sebagai pendukung promosinya dalam hal menarik minat dan kepercayaan konsumen.

Selain upload foto di atas fitur yang paling penting dan memiliki pengaruh yang sangat besar dalam memasarkan produk Fair N Pink untuk menaikkan tingkat penjualan, pemilik akun Fair N Pink Surabaya memanfaatkan fitur terbaru yaitu Instagram strories, sebuah fitur yang memungkinkan pengguna menggabungkan foto atau video menjadi satu dan di upload secara live. Fitur ini sangat cocok di gunakan pembisnis online dalam mempromosikan produk, sifatnya yang bisa di lihat secara langsung akan membuat konsumen tertarik untuk melihat dan tentunya menambah kepercyaan benar atau tidak adanya suatu produk yang di promosikan, selain itu content yang di upload dapat di poles dengan berbagai filter dan drawing tools sehingga pengguna bisa memodifikasi tampilanproduknya agar tampilannya lebih menarik. Seperti yang di lakukan Fair N Pink Surabaya dalam gambar di bawah ini.

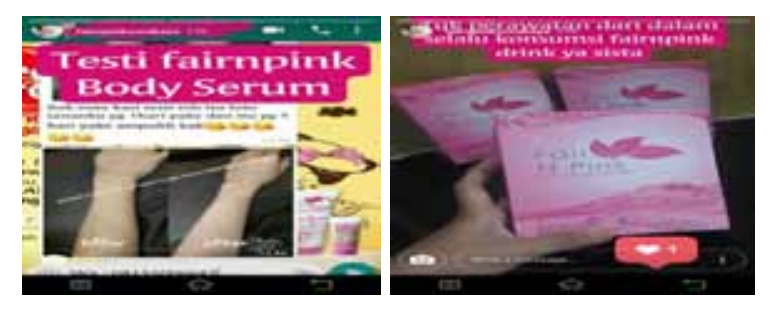

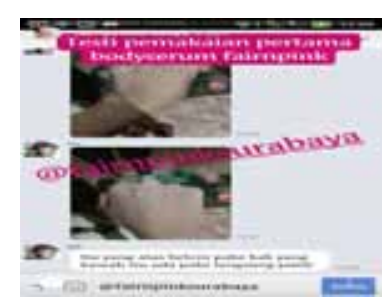

Gmabar 8. Stories Fair N Pink Surabaya

(Sumber: screenshots Instagram @

FairNPinkSurabaya oleh peneliti)

Seperti yang terlihat pada gambar 8. Fair $\mathrm{N}$ Pink Surabaya mempromosikan produknya menggunakan Stories yang di edit sedemikian rupa untuk menarik perhatian konsumen.

Judul foto atau caption merupakan keterangan yang biasanya berisi informasi mengenai foto yang di -upload dalam Istagram. Fitur ini di manfaatkan oleh Fair N Pink Surabaya untuk member nama pada setiap produk. Judul foto sangat penting agar konsumen mengetahui informasi produk yang di tawarkan oleh sebuah online shop, seperti pada gambar berikut:

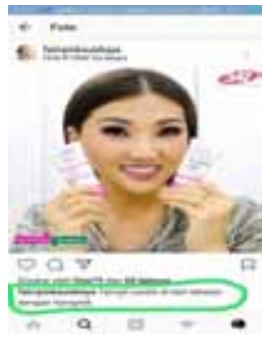

Gambar 9. Judul Foto

(Sumber: Screenshots Instagram @

FairNPinkSurabaya oleh peneliti)

Judul foto pada gambar 9. bermanfaat untuk memberikan informasi produk-yang di tawarkan dan dapat di manfaatkan juga sebagai media komunikasi dengan konsumen melalui kolom komentar yang tersedia tanpa harus memikirkan tambahan biaya. Seperti Twitter dan juga facebook, Istagram juga memiliki fitur yang dimana para penggunanya dapat menyinggung pengguna lain juga, dengan menambahkan tanda arroba (@) dan memasukkan akun Instagram dari pengguna tersebut seperti gambar 10. Fitur ini juga yang di gunakan Fair N Pink Suarabaya untuk memperkenalkan produknya pada masyarakat luas. Dimana banyak dari Fair N Pink Suarabaya lovers 
yang sering meng-upload foto mereka setelah membeli Fair N Pink kemudian di-upload pada akun Instagram mereka dan member tanda arroba (@) pada judul fotonya, seperti pada gambar di bawah ini:

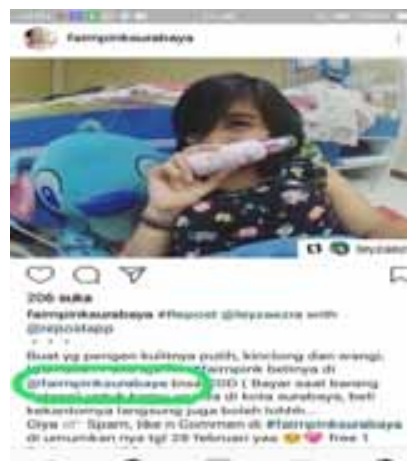

Gambar 10.Tandaarroba(@) pada postingan foto (Sumber : screenshots Instagram @ FairNPink oleh peneliti)

Setelah memasukan judul foto tersebut, bagian selanjutnya adalah bagian geotagging. Bagian dimana seseorang ingin berbagi dengan orang lain untuk informasi produk ataupun lokasi-lokasi wisata atau kuliner. Seperti yang terlihat pada gambar berikut ini:

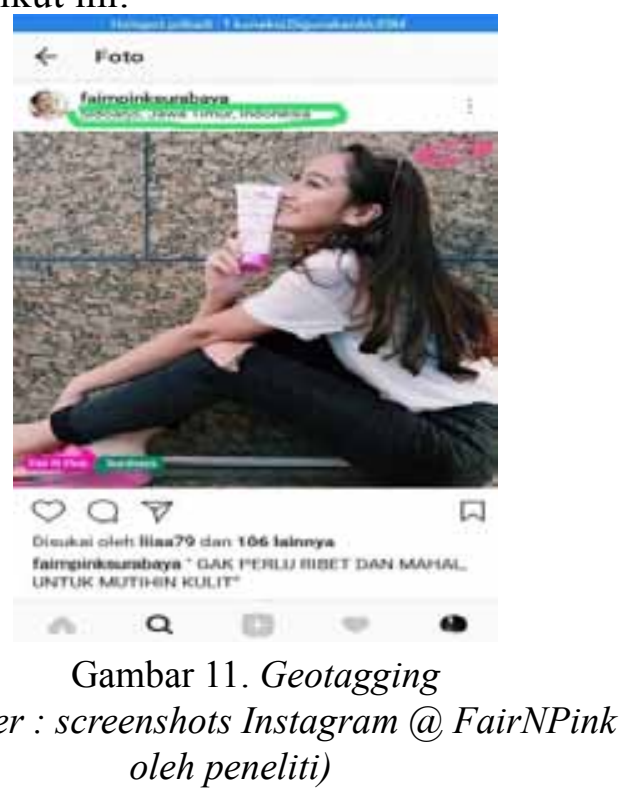

Pada gambar 11. terlihat lokasi dimana foto tersebut di-upload oleh akun Instagram Fair N Pink Surabaya. Lokasi tersebut adalah lokasi dimana sebuah produk dapat di peroleh, hampir sama dengan alamat tempat. Bagi setiap orang yang melihat postingan ini, bisa mendapat informasi tentang lokasi Fair N Pink Surabaya.

Dalam berbagi foto, para pengguna juga tidak hanya dapat membaginya di dalam Instagram saja, melainkan foto tersebut dapat dibagi juga melalui jejaring sosial lainnya, seperti Facebook, Twitter, Foursquare, Tumblr, dan Flickr yang tersedia di halaman Instagram untuk membagi foto tersebut.

Promosi melalui jejaring sosial adalah hal yang paling menguntungkan, maka dari itu setiap foto yang di-upload pasti selalu dibagian ke jejaring sosial lain seperti Facebook, twitter, foursquare, dan jejaring sosial yang didukung oleh Instagram. Oleh karena itu, pemilik usaha memanfaatkan fitur jejaring sosial pada Instagram untuk menghemat waktu saat meng-upload foto sebagai promosi. Di bawah ini (gambar 12) adalah tampilan fitur jejaring sosial yang ada di instagram:

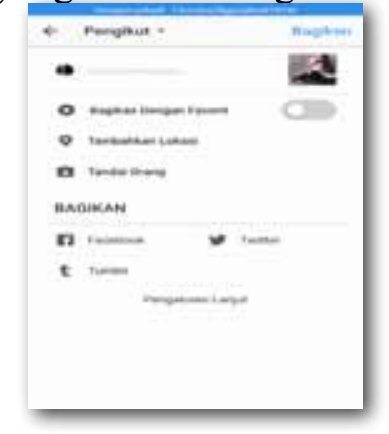

Gambar 12. Tampilan Fitur Jejaring Sosial (Sumber: screenshots Instagram @FairNPink suarabaya oleh peneliti)

Dalam hal ini, peneliti melihat kesempatan pemilik usaha untuk mengaitkan konsumen dari akun media sosial lain selain Instagram ini, berkaitan juga dengan salah satu sifat media bahwa media social dapat menjaukau target auddiencesi di seluruh dunia

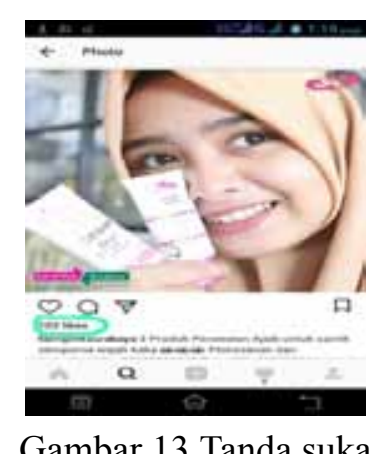

(Sumber: screenshotsInstagram@FairNPink suarabaya oleh peneliti) 
Instagram juga memiliki sebuah fitur tanda suka yang fungsinya memiliki kesamaan dengan yang disediakan Facebook, yaitu sebagai penanda bahwa pengguna yang lain menyukai foto atau video yang telah di-upload seperti gambar 12. Berdasarkan dengan durasi waktu dan jumlah suka pada sebuah foto atau video di dalam Instagram, hal itulah yang menjadi faktor khusus yang mempengaruhi foto tersebut terkenal atau tidak. Foto atau video yang di-upload oleh Fair N Pink Surabaya pun selalu mendapat respon yang baik dari Followers.

\section{SIMPULAN}

Strategi komunikasi pemasaran produk Fair $\mathrm{N}$ Pink melalui media sosial Instagram Fair N Pink Surabaya memanfaatkan Instagram dalam menjalankan strategi komunikasi pemasaran online dengan memanfaatkan fitur yang ada di dalam Instagram. Fair N Pink Suarabaya mempunyai strategi yang kreatif yang tidak di miliki oleh akun lain yang menjual produk serupa, pertama Fair N Pink Surabaya memberikan pelayanan COD (Cash On Delivery) dalam hal ini bertujuan untuk memberikan kenyaman dalam bertransaksi pada konsumen. Kedua Fair N Pink Suarabaya memberikan pelayanan free ongkos kirim dan potongan harga, dalam hal free ongkos kirim Fair N Pink Surabaya memberikan subsidi sebesar Rp. 20.000, jadi kalau ongkos kirimnya di bawah Rp. 20.000 biaya pengeriman gratis dan konsumen akan mendapatkan potongan harga jika membeli lebih dari tiga produk Fair N Pink. Ketiga menggunakan link bit.ly/FairnpinkSurabaya saat konsumen meng-clik link itu maka otomatis akan terhubung dengan kontak Whatsapp Fair N Pink Surabaya yang bisa di manfaatkan para konsumen jika ingin memesan ataupun sekedar tanya-tanya mengenai produk FairNPink, dalam hal ini Fair N Pink Surabaya memberikan kemudahan dalam berkomunikasi.

Dari beragam fitur pendukung bawaan Instagram tersebut, fitur yang paling sering digunakan pada tiap postingan Fair N Pink Surabaya adalah fitur stories, upload foto dan arroba(@). Fitur yang digunakan sangat bermanfaat dalam membantu proses promosi bagi Fair N Pink Surabaya. Seperti fitur stories, yang sifatnya live dapat menampilkan produk secara real, begitu juga dengan fitur upload foto, Fair N Pink Surabaya memanfaatkan promosi endorser sebagai pendukung promosi produknya. Dan juga melalui Instagram Fair N Pink Surabaya dapat dikenal secara luas oleh masyarakat, karena Instagram dapat menjangkau audiencesis secara luas. Dari beragam fitur yang dimiliki Instagram terdapat pula fitur-fitur yang tidak digunakan oleh Fair N Pink Surabaya, seperti fitur kamera dan efek foto. Fair N Pink Surabaya lebih memilih menggunkan kamera Digital untuk mendapatkan kualitas gambar yang lebih bagus dan menggunakan aplikasi editor foto untuk mendesain gambar agar lebih menarik.

Pemanfaatan fitur Instagram sebagai sarana strategi komunikasi pemasaran produk Fair N Pink yang dilakukan oleh pemilik usaha, sangat membantu dalam meningkatkan hasil penjualan Fair N Pink Surabaya. Dari hasil wawancara yang peneliti lakukan, peneliti mendapatkan hasil dari penjelasan pemilik usaha, kurang lebih dua tahun semenjak berdirinya Fair N Pink Surabaya ini, peningkatan penjualan yang dialami Fair N Pink Surabaya terus mengalami kenaikan sekitar 30 persen pada setiap harinya, setelah menggunakan akun media sosial Instagram. Ini membuktikan bahwa media sosial salah satu alat komunikasi pemasaran online yang tepat dalam sebuah penjualan online.

\section{DAFTAR PUSTAKA}

Adisaputro, Gunawan. 2010. Manajemen Pemasaran: Analisis Untuk Perancangan Strategi Pemasaran. Yogyakarta: YKPN.

Febriani, N.S. (2017). Faktor Kebudayaan Pendorong Munculnya Loyalitas pada Konsumen Kuliner Kota Kediri Jawa Timur. Jurnal Studi Komunikasi, 1(3). doi: 10.25139/jsk.v1i3.296

Hermawan, Agus. 2012. Komunikasi Pemasaran. Jakarta: Erlangga

Idrus, Muhammad. 2009. Metode Penelitian Sosial. Jakarta: Erlangga 
Moleong, Lexi J. 2010. Edisi Revisi. Metode Penelitian Kualitatif. Bandung: PT.Remaja Rosdakarya.

Pawito, 2007. Penelitian Komunikasi Kualitatif. Yogyakarta: LkiS.

Poetra, R. R., \& Christantyawati, N. 2017. Model AIDA: Pola Penggunaan Media Sosial dalam Meningkatkan Kepuasan Penjualan di Toko Online Goldies Hijab. Jurnal Komunikasi Profesional, 1(1).

Rafa'al, M. 2017. Identitas Gaya Hidup dan Budaya Konsumen dalam Mengkonsumsi Brand The Executive. Jurnal Komunikasi Profesional, 1(1).

Rahmat, Jalaluddin. 2004. Metode Penelitian Komunikasi. Bandung: PT Remaja
Rosdakaraya.

Riyadi, S., Sufa, S. A., \& Susilo, D. Strategic Marketing of Video on Facebook: Impacting Promotion of Malang Strudel Research Brief. Retrieved on: http://repository. unitomo.ac.id/296/1/JOERNAL \%20\%20 Strategic\%20Marketing\%20of\%20\%20 Video\%20on\%20Facebook.pdf

West, Richard, dan Lynn H. Turner. 2008. Pengantar Teori Komunikasi: Analisis dan Aplikasi, Edisi 3, terjemahan Maria Natalia Damayanti Maer. Jakarta: Salemba Humanika.

http://profile.print.kompas.com/tarif-iklan/_di akses pada 26 November 2016. 